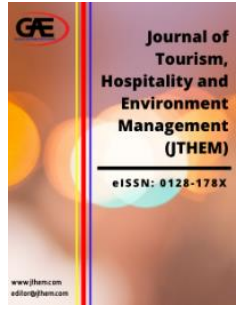

\author{
JOURNAL OF TOURISM, HOSPITALITY \\ AND ENVIRONMENT MANAGEMENT \\ (JTHEM) \\ www.jthem.com
}

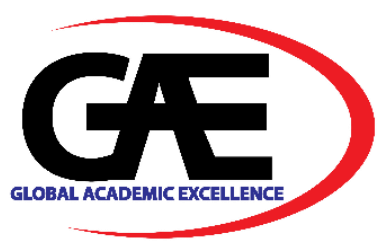

\title{
CULTURAL HERITAGE TOURISM: DETERMINANTS OF BEHAVIORAL INTENTION TO VISIT A HISTORICAL CITY FROM EXPERIENTIAL PERSPECTIVES
}

\author{
Wee Geot Fang ${ }^{1}$, Ahmad Azmi M. Ariffin ${ }^{2 *}$ \\ 1 Graduate School of Business, Universiti Kebangsaan Malaysia, Malaysia \\ Email: weegeofang@yahoo.com \\ 2 Graduate School of Business, Universiti Kebangsaan Malaysia, Malaysia \\ Email: aama@ukm.edu.my \\ Corresponding Author
}

\section{Article Info:}

Article history:

Received date: 23.12 .2020

Revised date: 29.12 .2020

Accepted date: 03.01.2021

Published date: 03.03.2021

To cite this document:

Wee, G. F., \& Ariffin, A. A. M (2021). Cultural Heritage Tourism: Determinants of Behavioral Intention To Visit A Historical City From Experiential Perspectives. Journal of Tourism, Hospitality and Environment Management, 6 (22), 0110.

DOI: 10.35631/JTHEM.622001.

This work is licensed under $\underline{\mathrm{CC} B Y}$ 4.0

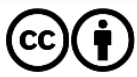

\begin{abstract}
:
The aim of this study is to investigate the determinants of behavioral intention to visit a historical city in the context of cultural heritage tourism from a marketing experiential perspective. Specifically, the main objective is to investigate the relative influence of the three experiential constructs identified as service experience, novelty experience, and leisure experience towards the tourist's intention to recommend and return to the historical city of Malacca. To the best knowledge of the researcher, this study is the first to incorporate all three variables together in a single research model. A total of 300 respondents consists of both local and foreign tourists were involved in this study. Data were collected around the historical city of Malacca, a popular UNESCO World Heritage Site in Malaysia. To qualify as the respondents of this study, the so-called cultural tourists must have been visiting the historical city for at least 2 days. Multiple Regression Analysis was employed to test all hypotheses developed in this study. The results showed that two of the independent variables namely leisure experience and service experience were found to have positive relationships with behavioral intention. Interestingly, this study found no evidence to support the relationship between novelty experience and behavioral intention in the context of cultural heritage tourism. Undeniably, the novelty of the cultural heritage tourism products is not the core determinant of tourist's revisit intention as well as favourable word-of-mouth as these products are considered as distinctive in nature and standing on their own.
\end{abstract}

\section{Keywords:}

Service Experience, Novelty Experience, Leisure Experience, Behavioral Intention, Cultural Tourism 


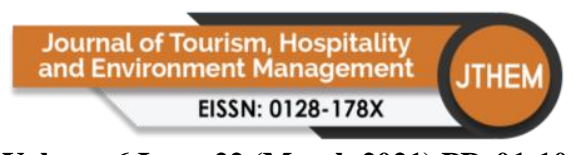

Volume 6 Issue 22 (March 2021) PP. 01-10

DOI 10/35631/JTHEM.622001

\section{Introduction}

Undeniably, tourism is one of the most important economic sectors in many countries throughout the world. The industry together with its hospitality counterpart contributes significantly to job creations, social development, infrastructure enhancement as well as other related industries (Ariffin, 2020). One of the most dominant form of tourism is cultural heritage tourism. Cultural heritage tourism essentially refers to the visit to places that reflects traditions, art forms, celebrations, and experience that portray the nation and its people (Ariffin \& Mansour, 2018). Cultural heritage tourists travel to experience the places like colonial palace, old canals, battlegrounds, etc., artifacts, and activities that authentically represent the stories and people of the past and present. According to Seyfi et al. (2020), although cultural tourism is regarded as a crucial component of tourism for many countries or destinations, not much details is currently available about the causative factors that shape the overall cultural tourism experience.

Findings from previous studies have shown that cultural tourism managed to generate higher income because of the cultural heritage travelers tend to stay longer and spend more money during if compare to other types of travelers due to they are motivated to learn or experience about the past or present beliefs, practices, art, cultural or heritage that possess by a group of identity people (Mansour \& Ariffin, 2017). Malacca is one of the most popular historical cities in Malaysia which had attracted a lot of foreign as well as local tourist (Jaafar et al., 2014). There are two elements involves in tourism which are tangible elements (transportation, accommodation, and other components of a hospitality industry) and intangible elements which refers to tourist's motivation and experience that possess from the vacation (Koutoulus, 2004). It is vital for service provider to being able to identify the reason of people travel and what can delight the $\mathrm{t}$ tourists due to tourism is related to human beings and human nature (Aziz \& Ariffin, 2009). The service providers in tourism industry not only need to ensure their service quality, but the ability to understand the tourist's psychological environment and experiential phenomena is also very important in order to permit the industry to perform better (Otto \& Ritchie, 1996). Quality of tourist experience will be affected by the service quality that provide by the contributor due to tourism is a business that comprise of many service sectors (Otto \& Ritchie, 1996). Domínguez-Quintero et al. (2020) recommended that the tourism product and service offering of the cultural heritage tourism attractions need to provide the tourists with an authentic tourism experience as well as excellent personalized experience to enhance the tourist satisfaction level with the cultural or heritage destinations.

The experiences aspect of tourism products and services is more focus on the affective factor which is related to mood, emotional, feeling, and attitude that experience by the tourist after involving in a vacation (Duman \& Mattila, 2005). Chen \& Chen (2010) also mention that experience quality is the psychological outcome result from tourist participation in the tourism activities. Currently, tourists are more likely to gaining new experience and search for unforgettable emotional memories (Ithnan and Ariffin, 2020). Heritage tourism is activities that related to experiential consumption, so tourist will tend to be perceived value more on the experience than the service provider (Chen \& Chen, 2010). However, there is not much research study on the experience quality of heritage tourism (Chen \& Chen, 2010). 


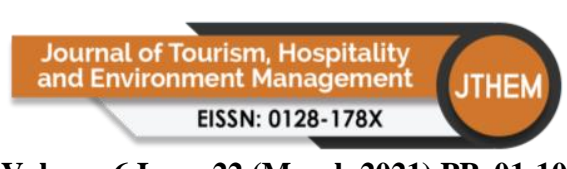

Volume 6 Issue 22 (March 2021) PP. 01-10

DOI 10/35631/JTHEM.622001

Novelty experience is one of the fundamental motivations driving services customers trying to find for new and various experiences as change from routine, escape, thrill, adventure, surprise and boredom alleviation (Cengiz \& Kirkbir, 2007). Based on the research done by Poria et al. (2004) and Poria et al. (2003), one of the motivations for tourists to involve in the heritage tourism is due to they are willing to observe and learn about the physical nature of the site, and its historic background. Leisure experience or serious leisure usually is formed by the amateurism, hobbyist pursuits, and career volunteering who attempts to express their abilities, fulfill their potential, and identifies themselves as unique human being through leisure. Cultural heritage tourist is travel to cultural heritage site as their hobby and the willingness to learn about others cultural. In order to fulfill their intention, they are travel more frequent, farther, and spend more money in order to get the knowledge that they want (Partners for Livable Communities, 2014). Cultural heritage tourism provides variety of lessons and values that benefit to current generation's identity based of the story that happened in the past. Based on the above discussion, presented below is the conceptual framework of this present study:

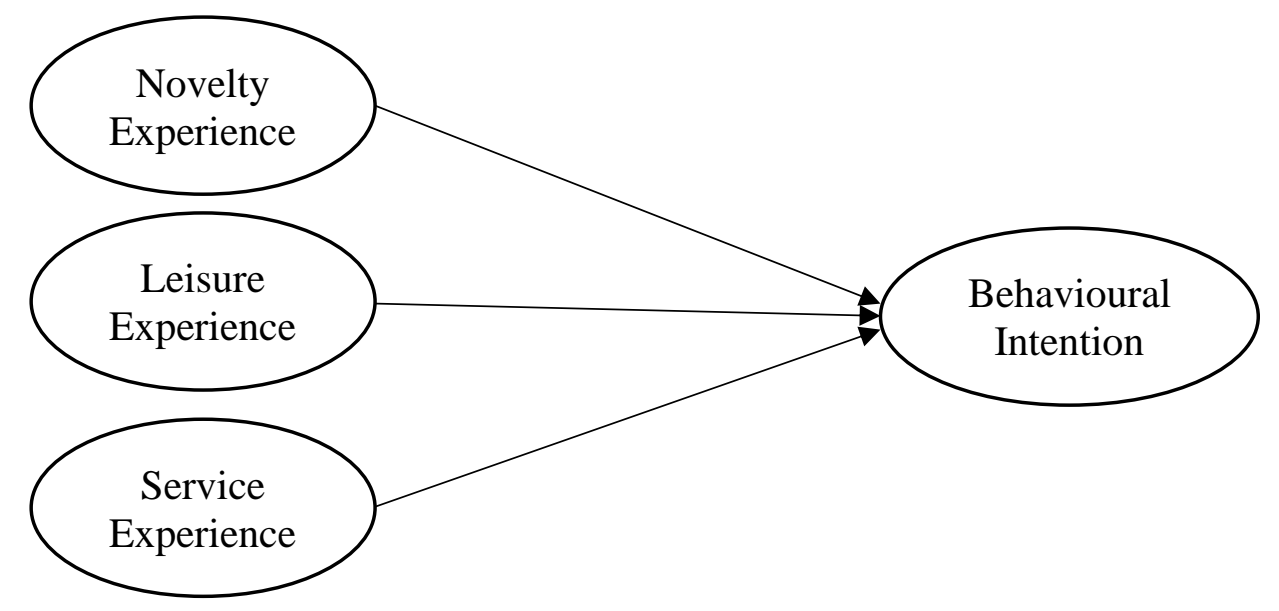

Figure 1: Conceptual Framework

\section{Literature Review}

Extant of literature indicated that the higher the levels of novelty will results higher level of satisfaction with the experience due to novelty is a desired attribute for travel experiences (Mathieson \& Wall, 1982; Ross \& Iso-Ahola, 1991). Novelty experiences is one of the elements of emotional dimension. Based on the result from Poria et al. (2004), one of the reasons for heritage tourists to visit cultural heritage sites is linked to the tourist's emotional involvement with the heritage presented which they are desire to gain heritage experience, historic cultural experience, and emotional experience from the heritage site. Besides that, novelty had motivates many tourist to seek for stimulation and adventure, find a new places to explore, and get a new things to learn (Lee \& Crompton, 1992). According to McKercher (2020) and Du Cros \& McKercher (2020), cultural tourism will continue to expand into the near as cultural tourists in particular are seeking for a genuine or authentic tourism experience. Cultural tourism is special interest tourism (Wen $\& \mathrm{Wu}, 2020$ ) due to in involve the activity of gaining knowledge about new cultural experiences no matter in the aesthetic, intellectual, emotional, or psychological perspective. Besides that, novelty also had become the driving 


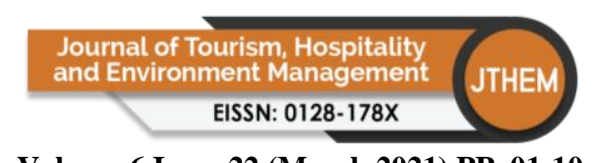

Volume 6 Issue 22 (March 2021) PP. 01-10

DOI 10/35631/JTHEM.622001

force for the memorable experience and tourist satisfaction (Sthapit, 2013; Zondo \& Ezeuduji, 2015). Thus, it is expected that:

H1: There is a significant relationship between novelty experience and behavioral intention in the context of cultural heritage tourism.

Kim et al. (2010) contended that involvement and knowledge that the tourists acquire in a particular tourism site are components that increase the tourist memorable tourism experience. Tourists that travel based on hobbies or undertaken leisure activities is most likely are enjoy and their self-actualization can be fulfilled (Nawijn, 2012). Tourists who are closely interact and involve in local cultural most likely to possess unique and memorable experience (Huh et al., 2006). There is relationship between perceived value and experience quality (Otto \& Ritchie, 1996). Besides that, cultural heritage tourism can be considered as serious leisure due to it has consists of education elements for example from museum, heritage site and so on (Packer \& Ballantyne, 2004). It is therefore anticipated in this present study that:

H2: There is a significant relationship between leisure experience and behavioral intention in the context of cultural heritage tourism.

Donovan and Rossiter (1982) had shown that when the tourists has a pleasure feeling towards to environment of the store, they tend to return the store and willing to talk to the employees in the store. Experience quality or service experience is an important indicator to increase customer satisfaction and customer loyalty (Zomerdijk \& Voss, 2010). Furthermore, customer revisit intention also one of the consequences from the high experience quality (Dong \& Siu, 2013; Kim \& Moon, 2009); Donovan \& Rossiter, 1982). Besides that, current satisfaction will effect on the future expectation, thus current service experiences is influenced by both anticipated and previous experience (Helkkula, 2012). Some past research also shows that, by increasing customer's experience quality can help service firm to pursue customer loyalty (Zomerdijk \& Voss, 2010). Besides that, Dong \& Siu (2013) had provide an empirical evidence that a positive service experience evaluation has a positive and significant relationship to both experience intensification and experience extension behavior or behavioral intention. The four dimensions of cruisers' experiences (entertainment, educational, escapist, and esthetic) have a direct effect on intention to recommend, and satisfaction also found to be partial mediator in the relationship between cruisers' experiences and intention to recommend (Hosany \& Witham, 2009). Besides that, in the study from Teo et al. (2014), they found that memorable tourism experience will increase the positive word-of-mouth about a heritage destination and the tourists are intend to have repeat visitation. Thus, it is suggested that:

H3: There is a significant relationship between service experience and behavioral intention in the context of cultural heritage tourism.

\section{Research Method}

This present study was carried out entirely in the historical city of Malacca in Peninsular Malaysia. Respondents were approached at the cultural heritage destinations or historical sites. The target population of this study was the cultural heritage tourists regardless of their nationalities. In order to be selected as the respondents, the tourists must be at least 18 years old and have been in Malacca for at least 2 days. A total of 300 cultural heritage tourists in Malacca city have been approached. By using quota sampling, half of the respondents or 150 were local tourists and the other half were foreign tourists. Even-though the samples of this 


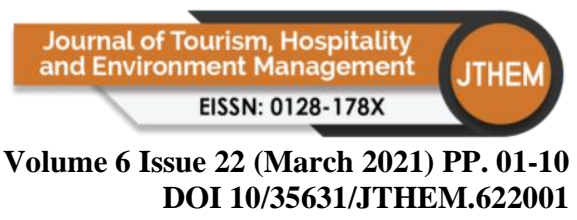

study include both local and foreign tourists, it was not the aim of this paper to compare the two parties in terms of their behavioral intention.

Questionnaire survey was employed as the main method of data collection. All measurements have been adapted from well-established scales. Multiple regression was used to test all the hypotheses. The data has also been checked to ensure all the requirements for multivariate analysis were met. The measurement for novelty experiences was adapted from Otto and Ritchie (1996) and consists of 7 items. Samples of the items were "I was being stimulated or challenge in some way" and "I was having a once in a lifetime experience". Leisure experiences was measured using 6 items fully adapted from Taheri et al. (2014) and Gould et al. (2008). The samples of the items - "Visiting Malacca helps me to express who I am" and "Visiting Malacca has a positive effect on how I feel about myself". Service experience was measured using 15 items borrowed from Otto and Ritchie (1996) and the samples of the items - "I am doing something new and different", and "I am being challenge in some way". Finally, behavioral intention was measured using 3 items from Zeithaml et al. (1996). The samples of the items were "I would recommend Malacca to other people", and "I would say positive things about Malacca as a cultural heritage destination". All items were measured on 6-point scale from strongly disagree to strongly agree.

\section{Findings}

A total of 300 cultural tourists were involved in this study and almost 60 percent of them were female. Large majority or around 63 percent were in the age bracket of 20 to 30 years old. Almost 45 percent hold a bachelor degree. The summary of the demographic profiles is presented below.

Table 1: Demographic Profile

\begin{tabular}{|l|c|c|c|}
\hline \multicolumn{1}{|c|}{ Demographic } & Descriptive & Frequency & Percentage \\
\hline Gender & Male & 121 & 40.3 \\
& Female & 179 & 59.7 \\
\hline Age & Below 20 & 41 & 13.7 \\
& $20-30$ & 185 & 61.7 \\
& $31-40$ & 41 & 13.7 \\
& $41-50$ & 17 & 5.7 \\
& $51-60$ & 10 & 3.3 \\
& 61 and above & 6 & 2.0 \\
\hline Level of Education & Lower than Diploma & 37 & 12.3 \\
& Diploma & 79 & 26.3 \\
& Bachelor Degree & 133 & 44.3 \\
& Postgraduate & 49 & 16.3 \\
& Others & 2 & 0.7 \\
\hline Occupation & Professional & 112 & 37.3 \\
& Non-Professional & 22 & 7.3 \\
& Student & 128 & 42.7 \\
& Unemployed / Retired & 14 & 4.7 \\
& Self-Employed & 21 & 7.0 \\
& Others & 3 & 1.0 \\
\hline
\end{tabular}




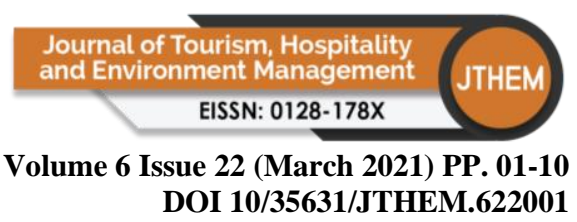

Below are the descriptive statistics of all the four variables involved in this study. The means for all variables were above 4.5 on a 6-point scale while the standard deviations were not larger than 1.18. The test for internal consistency also showed that all Cronbach's alphas were above 0.8 .

Table 2: Descriptive Statistics

\begin{tabular}{lcccccc}
\hline \multicolumn{1}{c}{ Main Constructs } & $\mathrm{n}$ & Means & S.D & Skewness & Kurtosis & C. Alpha \\
\hline Novelty Experience & 7 & 4.51 & 1.066 & -0.192 & -0.504 & 0.831 \\
Leisure Experience & 6 & 4.61 & 1.180 & -0.041 & -0.645 & 0.865 \\
Service Experience & 15 & 4.86 & 0.951 & -0.144 & -0.527 & 0.915 \\
Behavioral Intention & 3 & 5.63 & 1.165 & -0.760 & 0.154 & 0.861 \\
\hline
\end{tabular}

Table below summarized the results of the multiple regression analysis. The VIF for all variables were less than 10 indicating that there was no issue on multicollinearity. As represented by the value of $\mathrm{R}$ Square which was equal to 0.41 , the proposed three independent variables managed to explain 41 percents of the state of behavioral intention in the context of cultural heritage tourism. The results of the regression analysis revealed that only leisure experience $(\operatorname{Std}$ Beta $=0.345, \mathrm{Sig}=0.000)$ and service experience $($ Std Beta $=0.297$, Sig $=$ 0.000) were significantly related to behavioral intention. There was no empirical support for the relationship between novelty experience $(\operatorname{Std}$ Beta $=0.037, \mathrm{Sig}=0.621)$ and behavioral intention. Looking at the betas, leisure experience was found to be the more important determinant of behavioral intention compared to service experience.

Table 3: Multiple Regression Analysis

\begin{tabular}{|c|c|c|c|c|c|c|c|}
\hline \multirow[b]{2}{*}{ Model } & \multicolumn{2}{|c|}{$\begin{array}{c}\text { Unstandardized } \\
\text { Coefficients }\end{array}$} & \multirow{2}{*}{$\begin{array}{c}\begin{array}{c}\text { Standardized } \\
\text { Coefficients }\end{array} \\
\text { Beta } \\
\end{array}$} & \multirow[b]{2}{*}{$\mathbf{T}$} & \multirow[b]{2}{*}{ Sig. } & \multicolumn{2}{|c|}{$\begin{array}{c}\text { Collinearity } \\
\text { Statistics }\end{array}$} \\
\hline & B & S.E. & & & & Tolerance & VIF \\
\hline 3 (Constant) & 2.111 & .275 & & 7.686 & .000 & & \\
\hline Novelty Experience & .040 & .081 & .037 & .495 & .621 & .369 & 2.708 \\
\hline Leisure Experience & .341 & .070 & .345 & 4.871 & .000 & .406 & 2.464 \\
\hline Service Experience & .364 & .098 & .297 & 3.724 & .000 & .320 & 3.124 \\
\hline
\end{tabular}

a. Dependent Variable: Behavioral Intention

\section{Discussion}

The results of the study revealed that the quality of leisure experience was positively related behavioral intention in the context of cultural heritage tourism. Leisure experiences in the context of this study is referring to the ability of the destination to facilitate the tourists' motivations to enjoy themselves. The feeling of enjoyment is stimulated by the destination environmental characteristics or qualities as well as the nature of the destinations that promote education or exploration of new and novel things. Visiting a cultural heritage tourism attraction is indeed a leisure activity that are closely linked with the knowledge or educational motives. Tourists explore the attractions to learn new things or new culture about the place and its local people. The greater the knowledge that they can acquire from the experience of visiting the cultural and heritage sites, the more likely they will develop favorable behavioral intention towards the tourism attraction. In other words, they might want to return to the attraction or site again in the near future or recommend the destinations to other people to explore. In other words, the more distinctive the experience with the destinations and its tourism offering (as 


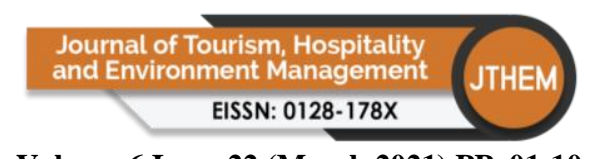

Volume 6 Issue 22 (March 2021) PP. 01-10

DOI 10/35631/JTHEM.622001

perceived by the tourists), the more likely it will lead to positive behavioral intention in the context of marketing outcomes.

The results of the study also showed that service experience was significantly related to behavioral intention. The more their senses are engaged while visiting the cultural heritage sites, the more memorable their tourism experience with the attraction. Past studies have shown that memorable tourism experience is one of the most powerful antecedents of marketing behavioral intention. The more they are able to immerse themselves in the cultural experience the more satisfied they will become with the tourism offerings. Service experience also relates to qualities of customer service offered by the tourism people at the cultural heritage destinations. Thus, in order to promote strong loyalty and favorable word-of-mouth, the operation staffs should be well-trained to serve the tourists in memorable manners. The great experience lives a great effect in the tourist mind and they are likely to recall the experience in their mind again and again.

Interestingly, this study found no empirical evidence to support the relationship between novelty experience and behavioral intention in the context of cultural heritage tourism. This result indicated that the novelty of the cultural heritage tourism products is not the core determinant of tourist's revisit intention as well as favourable word-of-mouth as these products are considered as distinctive in nature and standing on its own. This is perhaps due to the fact that novelty is not something that could be created by human. It is essentially natural. Therefore, the preferences are left to the individual tourists where some might not like it and do not have the desire to see or explore it again in the future. After all, for cultural heritage tourism offering, its "noveltiness" is only for the first timers as the offering is not in the position to be further improved or renovated like other tourism products or services.

The findings of this present study must be interpreted with some limitations. Firstly, the data of this present study were only gathered from a specific cultural heritage tourism destination, Malacca City in Malaysia. Therefore, the results might not be totally relevant or applicable to other cultural heritage tourism destinations due to the different in the environmental, cultural as well as social factors. Thus, future studies are recommended to include multiple tourism attractions or cities representing the various parts of the world. Secondly, since this study have shown strong relationships between leisure experience as well as service experience, and behavioral intention in the context of cultural heritage tourism, it is highly advisable for the future studies to include a moderator or a mediator that might affect the direct relationships mentioned above. The mediator and moderator will help explain how (underlying mechanism), why as well as when (under what situations) the intervention occurred.

\section{Conclusion}

From the theoretical perspective, this study has provided empirical evidence on the relationships between leisure experiences, service experience, novelty experiences and the state of behavioral intention in the context of cultural heritage tourism. All the three explanatory variables except novelty experience were found to be significantly related to loyalty as well intention to recommend the cultural heritage attractions to others. In terms of practical implication, since this study has provided evidence that leisure as well as service aspects are playing very important roles to ensure return visits of the tourists in the future as well as to recommend the destination to others, tourism authorities (of cultural destinations) need to 


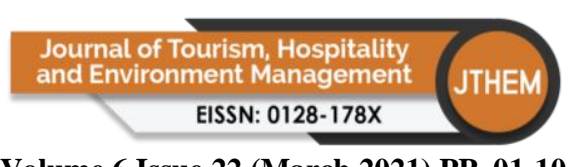

Volume 6 Issue 22 (March 2021) PP. 01-10

DOI 10/35631/JTHEM.622001

ensure that the tourism officials or service providers are well-trained and equipped with all the necessary skills to provide superb customer service to the cultural tourists. Apart from focusing on the continuous efforts to preserve the cultural heritage tourism product offerings, efforts must also be taken to ensure that the "leisure" aspects of the city or destination is not ignored. The destination must be well-panned and well-designed to ensure that the tourists are fully satisfied with the overall touristic experiences with the city. The memorable tourism experience generated would certainly bring them back to the tourism destination in the future. According to Malik (2020) the element of creative tourism is one of the most important facet of cultural heritage tourism that need to be developed as part of the effort to ensure its sustainability in the long run. Future research should be geared towards the issue of blending or bridging between creative tourism and cultural tourism.

\section{References}

Ariffin, A. A. M. (2020). Core Dimensions of Islamic Hotel Service: Towards Their promotion in the Global Marketplace. International Journal of Religious Tourism and Pilgrimage, 8(3).

Ariffin, A.A.M. \& Mansour, J.S. (2018). The Influences of Authenticity and Experience Quality on Behavioural Intention in Cultural Heritage Destination. WSEAS Transactions on Business and Economics. 15: 394-403.

Aziz, N. A. \& Ariffin, A. A. M. (2009). Identify the Relationship between Travel Motivation and Lifestyles among Malaysian Pleasure Tourists and Its Marketing Implications. International Journal of Marketing Studies, 1(2), 96 - 106.

Aziz, N. A., Ariffin, A. A. M., Omar, A. A., \& Yoon, S. K. (2011). An Investigation of International and Domestic Tourists' Satisfaction in Heritage Context: Implications for Destination Marketing. Jurnal Pengurusan, 33, 61 - 76.

Cengiz, E. \& Kirkbir, F. (2007). Customer Perceived Value: The Development of a Multiple Item Scale in Hospitals. Problem and Perspectives in Management, 5 (3), 252 - 267.

Chen, C. F. \& Chen, F. S. (2010). Experience Quality, Perceived Value, Satisfaction and Behavioral Intentions for Heritage Tourists. Tourism Management, 31, 29 - 35.

Chen, C. F. \& Tsai, D. (2006). How Destination Image and Evaluative Factors Affect Behavioral Intentions? Tourism Management, 28, 1115 - 1122.

Chen, Y. C., Shang, R. A., \& Li, M. J. (2014). The Effects of Perceived Relevance of Travel Blog's Content on the Behavioral Intention to Visit a Tourist Destination. Computers in Human Behavior, 30, 787 - 799.

Domínguez-Quintero, A. M., González-Rodríguez, M. R., \& Paddison, B. (2020). The mediating role of experience quality on authenticity and satisfaction in the context of cultural-heritage tourism. Current Issues in Tourism, 23(2), 248-260.

Dong, P., \& Siu, N. Y. M. (2013). Servicescape Elements, Customer Predispositions and Service Experience: The Case of Theme Park Visitors. Tourism Management, 36, 541 $-551$.

Donovan, R., J. \& Rossiter, J. R. (1982). Store Atmosphere: An Environmental Psychology Approach. Journal of Retailing, 58, $34-57$.

Du Cros, H., \& McKercher, B. (2020). Cultural tourism. Routledge.

Duman, T. \& Mattila, A. S. (2005). The Role of Affective Factors on Perceived Cruise Vacation Value. Tourism Management, 26, 311 - 323.

Gould, J., Moore, D., McGuire, F., \& Stebbins, R. (2008). Development of the serious leisure inventory and measure. Journal of Leisure Research, 40(1), 47-68. 


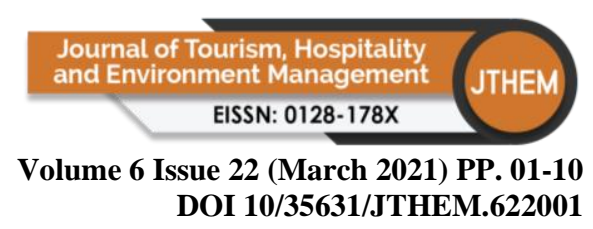

Helkkula, A., Kelleher, C. \& Pihlstrom, M. (2012). Characterizing Value as an Experience: Implications for Service Researchers and Managers. Journal of Service Research, 15 (1), $59-75$.

Hosany, S., \& Witham, Mark. (2009). Dimensions of Cruisers' Experiences, Satisfaction and Intention to Recommend. School of Management, Royal Holloway University of London, Working Paper Series.

Huh, J., Uysal, M., and McCleary, K. (2006). Cultural Heritage Destinations: Tourist Satisfaction and Market Segmentation. Journal of Hospitality and Leisure Marketing, 14 (3), 81 - 99.

Ithnan, I.H. \& Ariffin, A.A.M. (2020). Behavioral Intention Towards "Halal Hotels": Religiosity or Ethnicity?. WSEAS Transactions on Business and Economics. 15: 58-73.

Jaafar, R. E., Tambi, A. M. A., Sa'adin, I., \& Husain, H. (2014). Exploring Local and Foreign Visitors' Behaviors and Satisfaction with a World Heritage Site. Tourism, Leisure and Global Change, 1, 49-58.

Kim, J. H., Ritchie, J. R. B., \& McCormick, B. (2010). Development of a Scale to Measure Memorable Tourism Experiences. Journal of Travel Research, 51 (1), 12 - 25.

Kim, W. G., \& Moon, Y. J. (2009). Customers' cognitive, emotional, and actionable response to the servicescape: A test of the moderating effect of the restaurant type. International journal of hospitality management, 28(1), 144-156.

Koutoulas, D. (2004). Understanding the tourist product. In Interim symposium of the Research Committee on International Tourism of the International Sociological Association. May.

Lee, T. H., \& Crompton, J. (1992). Measuring Novelty Seeking in Tourism. Annals of Tourism Research, 19 (4), $732-751$.

Malik, Y. M. (2020). Cultural Tourism Destination Elements and Attributes: An Interpretive Planning. Journal of International Cooperation and Development, 3(2), 74-74.

Mansour, J.S. \& Ariffin, A.A.M. (2017) The Effects of Local Hospitality, Commercial Hospitality and Experience Quality on Behavioral Intention in Cultural Heritage Tourism, Journal of Quality Assurance in Hospitality \& Tourism, 18:2, 149-172,

Mathieson, A., \& Wall, G. (1982). Tourism: Economic, Physical, and Social Impacts. London: Longman.

McKercher, B. (2020). Cultural tourism market: a perspective paper. Tourism Review.

Nawijn, J. (2012). An Introduction to Leisure and Happiness. Leisure Travel and Happiness, NRIT Media, 13 - 29.

Otto, J. E. \& Ritchie, J. R. B. (1995). Exploring the Quality of the Service Experience: A Theoretical and Empirical Analysis. Advances in Service Marketing and Management: Research and Practices, 5, JAI Press.

Otto, J. E. \& Ritchie, J. R. B. (1996). The Service Experience in Tourism. Tourism Management, 17 (3), 165 - 174.

Otto, J. E. \& Ritchie, J. R. B. (2000). The Service Experience in Tourism. In C. Ryan, \& S. Page (Eds.), Tourism Management: Towards the New Millennium, Oxford: Elsevier Science Ltd.

Packer, J. M., \& Ballantyne, R. R. (2004). Is Educational Leisure A Contradiction in Terms?: Exploring the Synergy of Education and Entertainment. Annals of Leisure Research, 7 (1), $54-71$.

Partners for Livable Communities. (2014). Cultural Heritage Tourism. 


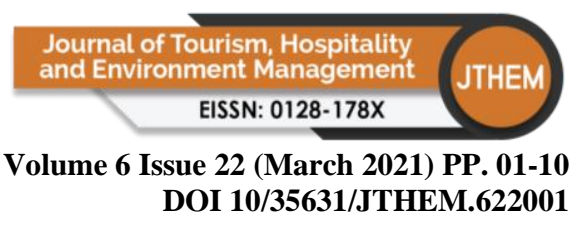

Poria, Y., Butler, R., \& Airey, D. (2003). The Core of Heritage Tourism. Annals of Tourism Research, 30 (1), $238-254$.

Poria, Y., Butler, R., \& Airey, D. (2004). Links between Tourists, Heritage, and Reasons for Visiting Heritage Sites. Journal of Travel Research, 43, 19 - 28.

Ross, E. L. D., \& Iso-Ahola, S. E. (1991). Sightseeing Tourists' Motivation and Satisfaction. Annals of Tourism Research, 18, 226 - 237.

Seyfi, S., Hall, C. M., \& Rasoolimanesh, S. M. (2020). Exploring memorable cultural tourism experiences. Journal of Heritage Tourism, 15(3), 341-357.

Sthapit, E. (2013). Tourist's Perceptions of a Memorable Experience: Testing the Memorable Tourism Experience Scale (MTEs) among Tourists to Rovaniemi, Lapland. Pro Gradu Thesis, Tourism Research EMACIM Studies.

Taheri, B., \& Jafari, A. (2014). 12 Museums as playful venues in the leisure society. Contemporary Tourist Experience: Concepts and Consequences, 27, 201-215.

Teo, C. B. C., Khan, N. R. M., \& Raham, F. H. A. (2014). Understanding Cultural Heritage Visitor Behavior: The Case of Melaka as World Heritage City. Procedia - Social and Behavioral Sciences, 130, $1-10$.

Wen, J., \& Wu, M. Y. (2020). How special is special interest tourism-and how special are special interest tourists? A perspective article in a Chinese context. Current Issues in Tourism, 1-5.

Zeithaml, V. A., Berry, L. L., \& Parasuraman, A. (1996). The behavioral consequences of service quality. Journal of marketing, 60(2), 31-46.

Zondo, P. K. \& Ezeuduji, I. O. (2015). Comparing Local and International Tourist's Perceptions of Service Experience Dimensions of An Attraction and A destination: The Case of South Africa. African Journal of Hospitality, Tourism, and Leisure, 4 (2), 1 15.

Zomerdijk, L. G. \& Voss, C. A. (2010). Service Design for Experience-Centric Services. Journal of Service Research, 13 (1), 67 - 82. 